\title{
Effects of temperature and host developmental stage on Ascosphaera torchioi Youssef and McManus prevalence in Osmia lignaria propinqua Cresson (Hymenoptera: Megachilidae)
}

\author{
R Rust $1^{*}, \mathrm{P}$ Torchio 2 \\ 1 University of Nevada, Department of Biology, Reno, NV 89557-0015; \\ 2 Utah State University, USDA ARS Bee Biology and Systematics Laboratory, \\ Logan, UT 84322-5310, USA
}

(Received 6 February 1991; accepted 8 July 1991)

\begin{abstract}
Summary - Eggs and fifth instar larvae of Osmia lignaria propinqua were inoculated with known concentrations of Ascosphaera torchioi spores and reared at 3 different temperatures. Chalk-brood prevalence was highest following inoculation of bees in the egg stage and when reared at lower temperatures $\left(21^{\circ} \mathrm{C}\right)$.
\end{abstract}

Osmia / chalk brood / mycosis / etiology

\section{INTRODUCTION}

The genus Ascosphaera includes fungi commonly found as pathogens of bee larvae and also as saprophytes within brood cells. Pathogenic species produce a disease syndrome referred to as chalk brood. Maassen (1916) was first to associate the chalky appearance of dead honey bee larvae to Ascosphaera apis (Maassen ex Claussen). Since that time, additional Ascosphaera species have been found to produce chalk brood in other bee taxa (Melville and Dade, 1944; Clout, 1956; Baker and Torchio, 1968; Bohart and Youssef, 1972; Skou, 1972; Thomas and Poinar, 1973; Youssef et al, 1985) including 2 economically important host species, the alfalfa leafcutting bee (Megachile rotundata (Fabricius)) and the blue orchard bee (Osmia lignaria propinqua Cresson).

Soon after techniques to manage large, commercial populations of the alfalfa leaf-

* Correspondence and reprints 
cutting bee were developed, the incidence of chalk brood (caused by Ascosphaera aggregata Skou) increased dramatically, and it is now the single most important mortality factor in commercial populations (Stephen and Undurraga, 1978; Stephen et al, 1981; Youssef et al, 1984). The blue orchard bee, an effective pollinator of orchard crops (Torchio, 1987, 1990), has a complex of 2 or 3 Ascosphaera species (Youssef et al, 1985). The most abundant species, Ascosphaera torchioi Youseff and McManus (Youseff and McManus, 1991; and as Ascosphaera sp 2 in Youssef et al, 1985), was present in $99 \%$ of the O I propinqua chalk-brood cadavers examined (496 or 500). Youssef et al (1985) demonstrated that $A$ torchioi had the potential to develop into an important disease syndrome of this bee as populations are increased for commercial use.

Virtually nothing is known about how $A$ torchioi enter cells of blue orchard bees or what factors control the prevalence of chalk brood in natural host populations. We therefore initiated several lines of investigation with $A$ torchioi and $O /$ propinqua to determine how this disease is spread in both wild and managed populations. Here, we present data on chalk brood prevalence at 3 incubation temperatures following inoculation of eggs and fifth instar larvae of the blue orchard bee with spores of $A$ torchioi.

\section{MATERIALS AND METHODS}

Ascosphaera torchioi from O I propinqua was used. Spores were obtained from larval cadavers recovered from nest blocks placed in Blacksmith Fork Canyon, $17.5 \mathrm{~km}$ south of Logan, Utah and Reno, Nevada. Nest blocks were placed in the field during the spring of 1988 and spores from resultant cadavers were used in this 1989 laboratory study. The cadavers were stored in gelatin capsules and overwintered at 4 " $\mathrm{C}$ prior to use.

\section{Experiment 1 (spore load)}

The number of spores per cadaver was estimated by dissecting $15 \mathrm{O} /$ propinqua larval cadavers from Reno, Nevada. The 15 cadavers represented the maximum size range available for study. Larval cadavers that had been isolated in gelatin capsules and overwintered at 4 " $\mathrm{C}$ were weighed to the nearest $0.1 \mathrm{mg}$. The outer surface of the larval cadaver was removed with a sterile razor blade and exposed spores and spore cysts were collected. The remaining larval "gut" was weighed and spore weight determined. The collected spores and spore cysts were then homogenized with $5 \mathrm{ml}$ distilled water and gently ground with a tissue homogenizer until samples showing the spores were separated from spore cysts. Spore concentration within the suspension was estimated by counting 10 aliquots in a hemocytometer.

\section{Experiments 2 and 3 (spore introduction)}

$O$ I propinqua cadavers from Blacksmith Fork Canyon, Utah were dissected and the spore cysts suspended in sterile distilled water as described above. The final suspension contained approximately 20 million spores per $\mathrm{ml}$. The suspension was maintained at 1 " $\mathrm{C}$ for $48 \mathrm{~h}$ before use as inoculum.

Active and recently completed nests of $O$ I propinqua were obtained from Blacksmith Fork Canyon, Utah on May 8, 1989, from block traps fitted with 7-mm diameter paper straws. Thirtynine groups of 20 newly completed cells (provision and embedded egg) were removed from the nest blocks. Individual cells were exposed by cutting along the top surface of the straw with a sterile razor blade in preparation to adding spores.

\section{Experiment 2 (temperature and stage at inoculation)}

Twenty-seven groups of cells (eggs on cell provisions) were divided into 9 treatment subgroups, each with 3 replications. The temperatures used were: 1) $21 \pm 0.5{ }^{\circ} \mathrm{C}$; 2) $25 \pm 0.5{ }^{\circ} \mathrm{C}$ : 
and 3) $29 \pm 0.5^{\circ} \mathrm{C}$ (all at $65 \pm 5 \% \mathrm{RH}$ ). For each temperature, 3 replications of 20 eggs each were treated in one of the following ways: 1) 2 applications of $25 \mu \mathrm{l}$ of sterile distilled water added to the surface of the provisions adjacent to the egg (control); 2) 2 applications of $25 \mu \mathrm{l}$ of the spore suspension ( $\approx 1$ million spores) added to the surface of the provisions adjacent to the egg; or 3) 2 applications of $25 \mu$ spore suspension added to the provisions after larvae reached the fifth instar (recognized by the dense setal pattern covering the body), but prior to defecation.

\section{Experiment 3 (spore concentration)}

Twelve groups of cells were divided into 4 treatment groups each with 3 replicates of 20 eggs. The treatments were: 1) sterile distilled water as above (control); 2) 1 million spores, as at the temperature - stage in the inoculation experiment; 3) one application of $25 \mu \mathrm{l}$ of spore suspension (500 000 spores); and 4) one application of $5 \mu \mathrm{l}$ of spore suspension (100 000 spores). Bees were incubated at $25 \pm 0.5^{\circ} \mathrm{C}$.

In Experiments 2 and 3 , both the sterile distilled water and spore suspension were applied on the surface of the provision immediately below the anterior tip of the egg where the eclosed larva first feeds. Any egg touched by the water or spore suspension before it was absorbed into the provision was eliminated from the study, and replaced with a fresh cell having an egg attached to the provision. Any larva that failed to reach the second instar (Torchio, 1989) was eliminated from the experiment. For treatment of fifth instar larvae, the spore suspension was placed near the head capsule of the feeding individual. The status of immatures was observed every other day. $O$ / propinqua chalk-brook cadavers representative of those used in this study have been deposited at the USDA ARS Bee Biology and Systematics Laboratory.

\section{Analyses}

The data from Experiment 1 were analyzed by one-way analysis of variance and regression. Data from experiments 2 and 3 on percent survi- val to the adult stage were analyzed by arcsine transformation of the percentage of individuals surviving to the adult stage in any replication. A 2-way analysis of variance testing the effects of rearing temperatures and stage at inoculation on the survival of treated individuals was used for Experiment 2, and a 1-way analysis of variance testing the effects of spore concentration on the survivorship of individuals tested was used for Experiment 3.

\section{RESULTS}

\section{Experiment 1 (spore load)}

There was a positive significant relationship between larval cadaver weight and both cadaver spore weight $(F=498.26$; $d f=1,13 ; P<0.001 ; Y=-2.12+0.525 X$; $\left.r^{2}=97.5 \%\right)$ and number of spores per cadaver $(F=143.38 ; d f=1,13 ; P<0.001$; $Y=-1.39+0.108 X ; r^{2}=91.7 \%$ ) (fig 1 ). The average weight of larval cadavers was $40.2 \pm 16.0 \mathrm{mg}(\mathrm{SD})(n=15$, range $24.7-$ 66.9) and the average weight of spores per cadaver was $19.0 \pm 8.52 \mathrm{mg}(n=15$, range $9.6-31.2)$. The average number of spores per cadaver was $2.9 \pm 1.8$ billion $(n=15$, range 1.0-6.0).

\section{Experiment 2 (temperature and stage at inoculation)}

The number of individuals surviving treatments with $\approx 1$ million spores of $A$ torchioi varied depending upon stage at inoculation and incubation temperature (table 1). Host stage had a highly significant effect on mortality levels $(F=21.051$; $d f=2,18$; $P \ll 0.001$ ). Survival rates were $98.2 \pm$ $2.5 \%$ for controls, $88.8 \pm 14.7 \%$ for fifth instar larvae, and $75.0 \pm 16.6 \%$ for the eggs. There was also a highly significant effect of temperature on survival $(F=15.888, d f=$ 


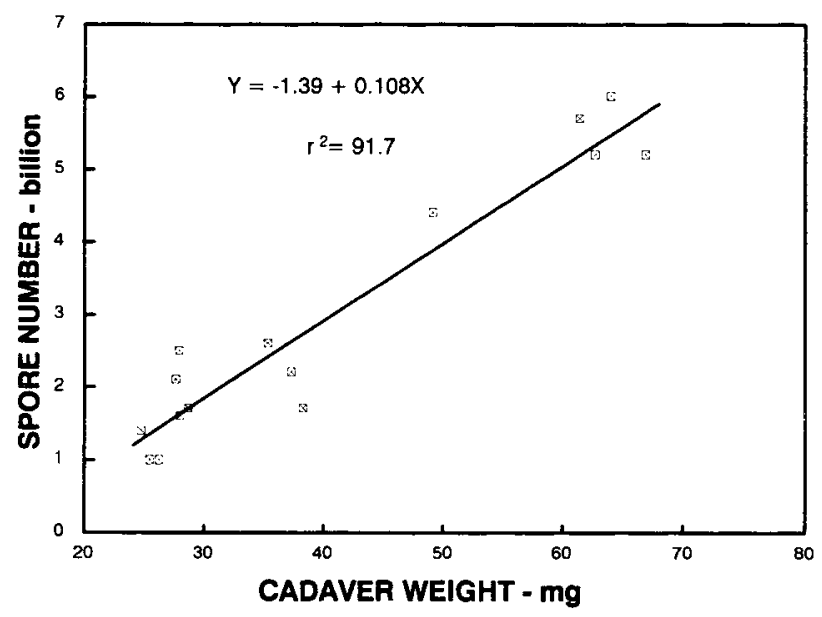

Fig 1. Regression analysis of Ascosphaera torchioi spores to larval cadavers of Osmia lignaria propinqua.

Table 1. Number and percentage of Osmia lignaria propinqua surviving treatment with 1 million spores of Ascospharea torchioi. Number in parentheses indicates number of larvae in replication, the difference from 20 equals egg death during embryogenesis or hatching and not death from Ascosphaera.

\begin{tabular}{|c|c|c|c|}
\hline \multirow[t]{2}{*}{ Replication } & \multicolumn{3}{|c|}{ Treatment } \\
\hline & $21^{\circ} \mathrm{C}$ & $25^{\circ} \mathrm{C}$ & $29^{\circ} \mathrm{C}$ \\
\hline \multicolumn{4}{|l|}{ Control } \\
\hline 1 & $18(19) \quad 94.7$ & $20(20) 100.0$ & $18(18) 100.0$ \\
\hline 2 & 19 (19) 100.0 & $19(20) \quad 95.0$ & 19 (19) 100.0 \\
\hline 3 & $20(20) 100.0$ & 18 (19) 94.7 & $20(20) 100.0$ \\
\hline \multicolumn{4}{|c|}{ Egg treatment } \\
\hline 1 & $11(18) \quad 61.1$ & $12(20) \quad 60.0$ & $20(20) 100.0$ \\
\hline 2 & $17(20) \quad 85.0$ & $12(19) \quad 63.1$ & $18(20) \quad 90.0$ \\
\hline 3 & $10(19) \quad 52.6$ & $14(19) \quad 73.6$ & $17(19) \quad 89.4$ \\
\hline \multicolumn{4}{|c|}{ Fifth instar treatment } \\
\hline 1 & $17(20) \quad 85.0$ & 19 (19) 100.0 & $19(19) 100.0$ \\
\hline 2 & $14(20) 70.0$ & 18 (19) 94.7 & $20(20) 100.0$ \\
\hline 3 & $12(20) \quad 60.0$ & $18(20) 90.0$ & $20(20) 100.0$ \\
\hline
\end{tabular}


$2,18$; $P<<0.001)$ with decreasing host survival at lower temperatures $\left(29^{\circ} \mathrm{C}-97.9 \pm\right.$ $4.5 \%, 25{ }^{\circ} \mathrm{C}-85.7 \pm 15.7 \%$, and $21^{\circ} \mathrm{C}-$ $78.7 \pm 18.2 \%$ ).

There was a significant interaction between stage at inoculation and incubation temperature $(F=3.767 ; d f=4,18 ; 0.05>$ $P>0.02)$. Treated eggs reared at 21 or $25{ }^{\circ} \mathrm{C}$ had the lowest survival rates $(66.2 \pm$ $16.7 \%$ and $65.6 \pm 7.1 \%$, respectively). Lower survival rates of inoculated fifth instar larvae also occurred at $21^{\circ} \mathrm{C}(71.6 \pm$ $12.5 \%$ ).

Eggs reared at $29^{\circ} \mathrm{C}$ reached the fifth instar in 4-5 days and had spun their cocoons or died of Ascosphaera infection 22-24 days after treatment. Eggs incubated at $25^{\circ} \mathrm{C}$ reached the fifth instar in 5-6 days and had completed their cocoons or died 22-26 days after treatment. However, eggs reared at $21{ }^{\circ} \mathrm{C}$ reached the fifth instar in 10-12 days and had completed their cocoons or died 35-40 days after treatment.

The first symptom of infection with A torchioi was observed after defecation and before initiation of cocoon spinning. Infected larvae were sluggish and produced only a few strands of silk. Their integument was clear with whitish fungal hyphae visible in the hemocoel about the larval gut.
The hyphae rapidly filled the hemocoel, turning the larva grey-white within $48 \mathrm{~h}$. The characteristic charcoal-black spore cysts appeared within $5-20$ days. At $21^{\circ} \mathrm{C}$, $73 \%$ of infected larvae (27 of 37 ) completed spinning at least the outer layers of the cocoon before death. Ten larvae died before spinning cocoon silk; of these 8 had been treated as eggs. At incubation temperatures of 25 and $29{ }^{\circ} \mathrm{C}$, most Ascosphaera induced deaths occurred before the larva had spun the outer silk of the cocoon. Some larvae (7 of 104) produced only a few silk strands.

\section{Experiment 3 (spore concentration)}

There was a highly significant difference in the survival of larvae that fed on provisions treated with different concentrations of $A$ torchioi spores $(F=10.13 ; \mathrm{df}=3,8 ; 0.01>$ $P>0.005$ ) (table II). Newman-Keuls multiple range test indicated that both the control (no spores) and $5 \mu$ (100 000 spores) treatment means were significantly different from the $50 \mu \mathrm{l}$ ( 1 million spores) and 25 $\mu l$ (500 000 spores) treatment means. They were also significantly different from each other. The control survival was $95 \pm$ $5.0 \%, 1$ million spore treatment survival

Table II. Number and percentage of Osmia lignaria propinqua surviving treatment with various spore concentrations of Ascospharea torchioi. Number in parentheses indicates number of larvae in replication, the difference from 20 equals egg death during embryogenesis or hatching and not from Ascosphaera.

\begin{tabular}{|c|c|c|c|c|}
\hline \multirow[t]{2}{*}{ Rep } & \multicolumn{4}{|c|}{ Spore No } \\
\hline & 1000000 & 500000 & 100000 & 0 \\
\hline 1 & $12(20) 60.0$ & $12(20) 60.0$ & $12(19) 63.1$ & $20(20) 100.0$ \\
\hline 2 & $10(17) 58.8$ & 16 (19) 84.2 & 7 (19) 36.8 & $19(20) \quad 95.0$ \\
\hline 3 & $14(19) 73.6$ & $10(18) 55.5$ & $6(20) 30.0$ & $18(20) \quad 90.0$ \\
\hline
\end{tabular}


was $64.1 \pm 8.2 \%, 500000$ spore treatment survival was $66.5 \pm 15.4 \%$, and 100000 spore treatment survival was $43.3 \pm$ $17.5 \%$.

\section{DISCUSSION}

The relationship between cadaver size and number of $A$ torchioi spores per cadaver in $O$ / propinqua is similar to that reported by Vandenberg et al (1980) for Megachile rotundata larvae infected with Ascosphaera aggregeta. Vandenberg et al (1980) found an average of $8.9 \times 10^{7}$ spores (range $3.2 \times 10^{6}$ to $5.3 \times 10^{8}$ ) in $M$ rotundata cadavers ranging from 5 to 25 $\mathrm{mg}$ dry weight. O I propinqua cadavers are much larger (mean cadaver weight 40.2 $\mathrm{mg}$ ) and had more spores per unit body weight on average $(1.8 \times 109)$ than $M$ ro tundata.

The symptoms of chalk brood observed in $O$ I propinqua are similar to those described by Youssef et al (1985) for their Ascosphaera sp 2 and parallel those observed in larvae of $M$ rotundata inoculated with spores of $A$ aggregata (Vandenberg and Stephen, 1982; McManus and Youssef, 1984). In our study, A torchioi did not penetrate the integument of the larva and did not develop aerially as reported for Ascosphaera proliperda on both $M$ rotundata (Youssef et al, 1984) and $O /$ propinqua (Youssef et al, 1985).

The pathogenicity of $A$ torchioi on $\mathrm{OI}$ propinqua appears to be influenced by temperature. Low temperature doubled the developmental time from second instar (the first stage to consume pollen-nectar provisions (Torchio, 1989)) to a cocoonspinning fifth instar larva. This increase in developmental time increases the probability that Ascosphaera spores will: 1) be ingested by the feeding larva; 2) germinate in the larval gut lumen; 3), penetrate the gut wall; 4), invade the hemocoel; and 5), sporulate before defecation begins and the content of the larval gut can be voided. Individuals reared at $29^{\circ} \mathrm{C}$ reached the defecating larval stage after 5-6 days, whereas individuals reared at $21^{\circ} \mathrm{C}$ required more than twice that time (12-14 days). This suggests that chalk-brood mortality in the field will increase whenever larval development is prolonged due to cooler temperatures.

Mortality resulting from a decrease in spore numbers and water carrier suggests that relatively few spores (100 000) will induce an infection. The high mortality level at the lowest spore suspension rate $(56.7 \%)$ may have resulted from an increase in spore concentration at the feeding site due to the lower inoculum volume and reduced spread of the spores throughout the provision. Youssef et al (1985) recorded $39.4 \%$ infectivity with $100 \quad 000$ spores and a rearing temperature of $20{ }^{\circ} \mathrm{C}$ and a $48 \%$ infectivity when larvae were inoculated with 10 million spores and reared at $30{ }^{\circ} \mathrm{C}$. In both their treatments, the spores were suspended in one drop of water from a 25-gauge needle. These differences suggest that a laboratory bioassay and dosage response curve should be developed using fewer spores and average rearing temperatures.

\section{ACKNOWLEDGMENTS}

We thank G Trostle (USDA, ARS, Bee Biology and Systematics Laboratory, Logan, Utah) for placing traps at Blacksmith Fork Canyon and D Sisson (Utah State University) for consultations with the statistical analysis. N Youssef (Utah State University) and $J$ Vandenberg (USDA ARS Bee Biology and Systematics Laboratory, Logan, Utah) reviewed the manuscript. This paper is a contribution from Utah State Agriculture Experiment Station, Journal Paper No 3963, and the Bee Biology and Systematics Laboratory, ARS, USDA. Utah State University, 
UMC 5310, Logan, Utah, and the Department of Biology, University of Nevada, Reno, from which RWR was on sabbatical leave.

\section{Résumé - Action de la température et du stade de développement de l'hôte sur la fréquence d'Ascosphaera torchioi Youssef et McManus chez Osmia ligna- ria propinqua Cresson (Hymenoptera:} Megachilidae). On ne connaît rien sur la façon dont Ascosphaera torchioi pénètre dans les cellules d'Osmia lignaria propinqua ni sur les facteurs qui contrôlent la fréquence du couvain plâtré dans les popula tions naturelles. Nous apportons des renseignements sur la fréquence $d^{\prime}$ Ascosphaera à 3 températures d'incubation après inoculation des œufs et des larves de $5^{\circ}$ stade.

Les œufs et les larves ont été traités avec des spores en suspension dans de l'eau distillée aux doses respectives de 1 million, 500000 et 100000 spores pour $50 \mu l, 25 \mu l$ et $5 \mu l$ de suspension. L'inoculum a été appliqué à la surface des provisions de nourriture sous l'extrémité antérieure de l'œuf ou de la larve. Les œuts et les larves ont été élevés à 3 températures : 21,25 et $29{ }^{\circ} \mathrm{C}$ à $65 \%$ d'humidité relative. Chaque traitement comportait 3 ré pétitions portant chacune sur 20 œufs ou larves. La concentration en spores par cadavre de larve a été déterminée en préle vant la surface extérieure des cadavres afin de mettre à nu les spores et sporocystes. Une fois récoltés, les spores et sporo cystes ont été homogénéisés dans de l'eau distillée, broyés avec un homogénéi seur de tissus et comptés avec un hématimètre.

II existe une relation positive significative entre d'une part le poids des cadavres de larves et d'autre part le poids et le nombre de spores par larve. Le nombre moyen de spores par larve est de 2,9 $\pm 1,8.10^{9}$ pour des cadavres pesant environ 40,2 \pm $16,0 \mathrm{mg}$. Le stade auquel l'hôte est inoculé a un effet hautement significatif sur le taux de mortalité : $98,2 \pm 2,5 \%$ de survie des témoins (pas de spores) contre $88,8 \pm 14,7 \%$ de survie des larves de $5^{\mathrm{e}}$ stade et $75,0 \pm$ $16,6 \%$ de survie des œufs. L'effet de la température est également hautement significatif. La survie de l'hôte décroît avec la température : $97,9 \pm 4,5 \%$ de survie à $29^{\circ} \mathrm{C}, 85,7 \pm 15,7 \%$ de survie à $25^{\circ} \mathrm{C}$ et $78,7 \pm 18,2 \%$ de survie à $21^{\circ} \mathrm{C}$. L'action combinée de la température et du stade d'inoculation est significative : les œufs élevés à $21^{\circ} \mathrm{C}$ ont le plus bas taux de survie $(66,2 \pm 16,7 \%)$, les larves de $5^{\mathrm{e}}$ stade élevées à $29^{\circ} \mathrm{C}$ ont le taux le plus fort $(100 \%)$.

II y a une différence significative entre les taux de survie des larves en fonction de la concentration en spores de l'inoculum. Des larves traitées avec 100000 spores chacune n'ont eu qu'un taux de survie de $43,3 \pm 17,5 \%$. Le fait que la mortalité la plus élevée soit obtenue avec la concentration en spores la plus faible peut s'expliquer par un accroissement de la consommation de spores par les larves dû à un volume d'eau plus faible de l'inoculum et par suite à la concentration des spores à proximité de la larve qui se nourrit. Un test biologique de laboratoire et une courbe dose-réponse devraient donc être mis au point avec une faible quantité de spores et des températures d'élevage moyennes.

Le pouvoir pathogène d'A torchioi vis-à vis de $O$ I propinqua semble ètre influencé par la température d'élevage. Une température basse double la durée de développerment jusqu'à la larve de $1^{\text {er }}$ stade qui file de cocon. Cet accroissement augmente la probabilité pour que les spores d'Ascosphaera 1) soit ingérées par la larve en se nourrissant, 2) germent dans l'intestin de la larve, 3) pénètrent la paroi de l'intestin, 4) envahissent l'hémocoele et 5) sporulent 
avant que la défécation n'ait lieu et que le contenu de l'intestin puisse être évacué. Tout ceci laisse penser que la mortalité au champ par le couvain plâtré augmentera si le développement larvaire est prolongé à cause de températures fraîches.

\section{Osmia / couvain plâtré / mycose / étio- logie}

Zusammenfassung - Einfluß von Temperatur und Entwicklungsstadium des Wirtes auf die Ausbreitung von Ascosphaera torchioi bei Osmia lignaria propinqua Cresson (Hymenoptera: Megachilidae). Es ist nichts darüber bekannt, wie Ascosphaerea torchioi in die Zellen von Osmia lignaria propinqua, der Blauen Obstgartenbiene, eindringt und welche Faktoren das Überhandnehmen der Kalkbrut in natürlichen Populationen kontrollieren. Wir legen hier Informationen über die Ausbreitung von Ascosphaera bei drei Bruttemperaturen nach Impfung von Eiern und Larven des 5-Stadiums vor. Eier und Larven wurden mit Sporen in sterilem destillierten Wasser behandelt, wobei Dosen von 1 Million, 500000 und 100000 Sporen $(50 \mu \mathrm{l}, 25 \mu \mathrm{l}$ und $5 \mu \mathrm{l})$ der Suspension verwendet wurden. Die Impfflüssigkeit wurde auf der Oberfläche der Nahrungsvorräte, unterhalb des Vorderendes des Eis oder der Larve, ausgebracht. Die Eier und Larven wurden bei einer rel Feuchtigkeit von $65 \%$ in drei verschiedenen Temperaturen aufgezogen: 21, 25 und $29^{\circ} \mathrm{C}$. Alle Versuche bestanden aus 3 Wiederholungen zu je 20 Eiern oder Larven. Die Sporenkonzentration per Larvenkadaver wurde durch Entfernung der äußeren Oberfläche des Körpers bestimmt, um die Sporen und Sporenzysten freizulegen.Die aufgenommenen Sporen und Zysten wurden mit destilliertem Wasser homogenisiert, in einem GewebeHomogenisator verrieben und in einem
Haemozytometer gezählt. Es ergab sich eine positive signifikante Beziehung zwischen dem Gewicht des Larvenkörpers und sowohl dem Gewicht wie der Zahl der Sporen per Larven. Die mittlere Sporenzahl per Larvenkadaver betrug $2.9 \pm 1.8$ Milliarden bei einem mittleren Kadavergewicht von $40.2 \pm 16.0 \mathrm{mg}$. Die WirtsImpfansätze hatten einen hochsignifikanten Effekt auf die Mortalität. Während die Kontrollen (ohne Impfung) eine Überlebensrate von $98.2 \pm 2.5 \%$ aufwiesen, sank diese auf $88.8 \pm 14.7 \%$ bei Impfung von Larven des 5-Stadiums und auf $75.0 \pm$ $16.6 \%$ bei Impfung von Eiern. Es zeigte sich auch ein signifikanter Temperatureinfluß mit einem fallenden Überleben des Wirts bei niedrigeren Temperaturen (29$97.9^{\circ} \mathrm{C} \pm 4.5 \%$ Überleben, $25-85.7^{\circ} \mathrm{C} \pm$ $15.7 \%$ Überleben, und $21-78.7{ }^{\circ} \mathrm{C} \pm$ $18.2 \%$ Überleben). Die kombinierte Wechselwirkung von Temperatur und Stadium der Impfung war signifikant: behandelte Vorräte mit $\mathrm{Ei}$, aufgezogen bei einer Temperatur von $21^{\circ} \mathrm{C}$, hatten mit $66.2 \pm 16.7 \%$ die niedrigste Überlebensrate, geimpfte Larven des 5-Stadiums, aufgezogen bei $29^{\circ} \mathrm{C}$, die höchste (100\%). Es bestand ein signifikanter Unterschied zwischen den Überlebensraten von Larven, die mit unterschiedlicher Sporenkonzentrationen behandelt worden waren. Eine Überlebensrate von nicht mehr als $43.3 \pm 17.5 \%$ wurde erzielt, wenn die Einzellarve mit je 100000 Sporen behandelt wurden. Die höchste Sterblichkeit bei gleichzeitig niedrigster Sporendosierung scheint durch eine Erhöhung der Sporenaufnahme bei Fütterung der Larven mit einer Suspension von geringerem Wassergehalt und daher niedrigerem Volumen und einer Konzentration der Sporen nahe der fressenden Larve erreicht zu werden. Das legt nahe, einen Laborbiotest und eine Kurve der Dosisabhängigkeit bei geringerer Sporenzahl und mittlerer Aufzuchttemperatur zu entwickeln. Die Pathogenität von $A$ torchioi für $O$ I propinqua 
scheint von der Aufzuchttemperatur beeinflußt zu werden. Niedrige Temperaturen verdoppelten die Entwicklungszeit zur kokonspinnenden Larve des I Stadiums. Diese Steigerung der Entwicklungszeit erhöht die Wahrscheinlichkeit, daß Ascosphaera-Sporen: 1) durch die fressende Larve aufgenommen werden; 2) im Darm der Larve keimen; 3) durch die Darmward dringen; 4) in die Körperhöhle eindringen; und 5) Sporen bilden bevor die Defäkation beginnt und der Darminhalt entleert werden kann. All dies läßt vermuten, daß die Kalkbrutmortalität im Feld zunehmen wird, sobald die Larvenentwicklung durch kühleres Wetter verlängert wird.

\section{Osmia / Kalkbrut / Mykose / Ätiologie}

\section{REFERENCES}

Baker GM, Torchio PF (1968) New records of Ascosphaera apis from North America. Mycologia 60, 189-190

Bohart GE, Youssef NN (1972) Notes on the biology of Megachile (Megachiloides) umatilensis Mitchell (Hymenoptera: Megachilidae) and its parasites. Trans $R$ Entomol Soc Lond 124, 1-19

Clout GA (1956) Chalk brood and hunchback flies. Bee Craft 38, 135

Maassen A (1916) Über Bienenkrankheiten. Mitt Biol Anst Land Fortsn 16, 51-58

McManus WR, Youssef NN (1984) Life cycle of the chalk-brood fungus, Ascosphaera aggregata in the alfalfa leafcutting bee, Megachile rotundata and its associated symptomology. Mycologia 76, 830-842

Melville R, Dade HA (1944) Chalk-brood aftacking a wild bee. Nature (Lond) 153, 112

Skou JP (1972) Ascosphaerales. Friesia 10, 1-24
Stephen WP, Undurraga JM (1978) Chalk-brood disease in the leafcutting bee. Bull Ore State Univ Agric Exp Stn No 630

Stephen WP, Vandenberg JD, Fichter BL (1981) Etiology and epizootiology of chalk brood in the alfalfa leafcutting bee, Megachile rotundata, with notes on Ascosphaera species. Bull Ore State Univ Agric Exp Stn No 653

Thomas GM, Poinar GE (1973) Report of diagnoses of diseases insects, 1962-1972. Hilgardia 42, 261-359

Torchio PF (1987) Use of non-honey bee species as pollinators of crops. Proc Entomol Soc Ont 18, 1-32

Torchio PF (1989) In nest biologies and immature development of three Osmia species (Hymenoptera: Megachilidae). Ann Entomol Soc Am 82, 599-615

Torchio PF (1990) Diversification of pollination strategies for US crops. Environ Entomol 19, 1649-1656

Vandenberg JD, Fichter BL, Stephen WP (1980) Spore load of Ascosphaera species on emerging adults of the alfalfa leafcutting bee, Megachile rotundata. Appl Environ Microbiol 39, 650-655

Vandenberg JD, Stephen WP (1982) Etiology and symptomatology of chalk-brood in the alfalfa leafcutting bee, Megachile rotundata. $J$ Invertebr Pathol 39, 133-137

Youssef NN, Roush CF, McManus WR (1984) In vivo development and pathogenicity of Ascosphaera proliperda (Ascosphaeaceae) to the alfalfa leafcutting bee, Megachile rotundata. J Invertebr Pathol 43, 11-20

Youssef NN, McManus WR, Torchio PF (1985) Cross-infectivity potential of Ascosphaera spp (Ascomycetes: Ascosphaera) on the bee, Osmia lignaria propinqua Cresson (Megachilidae: Osmia). J Econ Entomol 78, 227-231

Youssef NN, McManus WR (1991) Ascosphaera torchioi sp nov, a pathogen of Osmia lignaria propinqua Cresson (Hymenoptera: Megachilidae). Mycologia (in press) 